\section{Inhibition of dengue virus serotype 2 in Vero cells with [Cu(2,4,5-triphenyl-1H-imida- zole $\left.)_{2}\left(\mathrm{H}_{2} \mathrm{O}\right)_{2}\right] \cdot \mathrm{Cl}_{2}$}

\author{
Teguh H. Sucipto, ${ }^{1}$ Fahimah Martak ${ }^{2}$ \\ ${ }^{1}$ Dengue Study Group, Institute of \\ Tropical Disease, Universitas Airlangga, \\ Jl. Mulyorejo, Surabaya, East Java; \\ ${ }^{2}$ Department of Chemistry, Faculty of \\ Science, Institut Teknologi Sepuluh \\ Nopember, Jl. Raya ITS, Surabaya, East \\ Java, Indonesia
}

\begin{abstract}
Dengue fever and dengue hemorrhagic fever are transmitted to humans by the Aedes aegypti and Aedes albopictus mosquitoes, with an observed 30-fold increase in global incidence the last 50 years. Despite the tremendous efforts invested anti-dengue virus research, no clinically approved vaccine or antiviral chemotherapeutics are available for humans, and disease treatment is limited to supportive care. Over the years there has been a continuous interest in the chemistry of metal complexes with biological activity, including platinum complexes with antitumor activity and silver complexes with antimicrobial action. Aim of the project was to investigate $[\mathrm{Cu}(2,4,5$-triphenyl- $1 H$ imidazole $\left.)_{2}\left(\mathrm{H}_{2} \mathrm{O}\right)_{2}\right] \cdot \mathrm{Cl}_{2}$ as antiviral compound that was further tested for inhibitory effect on the replication of dengue virus type 2 (DENV-2) in Vero cell. DENV-2 were infected in Vero cells and replication of virus was measured by Viral ToxGlo with selectivity index value (SI) and determined as the ratio of cytotoxic concentration $50\left(\mathrm{CC}_{50}\right)$ to inhibitory concentration $50\left(\mathrm{IC}_{50}\right)$ for compound. The standard curve between concentration of compound $(\mu \mathrm{g} / \mathrm{mL})$ and \%viability of cells was analyzed by logarithmic correlation regression with regression equation. For infection rates, t-test was used to examine the statistical significances among the concentrations of compound. $\mathrm{P}<0.05$ was considered to be significant. The maximum inhibitory concentration $\left(\mathrm{IC}_{50}\right)$ of $[\mathrm{Cu}(2,4,5$ triphenyl- $1 \mathrm{H}$-imidazole $\left.)_{2}\left(\mathrm{H}_{2} \mathrm{O}\right)_{2}\right] \cdot \mathrm{Cl}_{2}$ against DENV-2 was $98.62 \mu \mathrm{g} / \mathrm{mL}$. The cytotoxic concentration $\left(\mathrm{CC}_{50}\right)$ of compound against Vero cells was $300.36 \mu \mathrm{g} / \mathrm{mL}$. The SI values for $\quad\left[\mathrm{Cu}(2,4,5 \text {-triphenyl- } 1 \mathrm{H} \text {-imidazole })_{2}\right.$ $\left.\left(\mathrm{H}_{2} \mathrm{O}\right)_{2}\right] \cdot \mathrm{Cl}_{2}$ 1.86. Based on selectivity index values, $\left[\mathrm{Cu}(2,4,5 \text {-triphenyl- } 1 \mathrm{H} \text {-imidazole })_{2}\right.$ $\left.\left(\mathrm{H}_{2} \mathrm{O}\right)_{2}\right] \cdot \mathrm{Cl}_{2}$ can inhibit the growth of DENV2 and has low toxicity values for Vero cells.
\end{abstract}

\section{Introduction}

Dengue virus (DENV) is an arthropodborne disease that causes serious for human, distributed in the tropical and sub-tropical areas. $^{1-3}$ Vaccines and effective antiviral of dengue virus treatments are still missing, the presence of four distinct serotypes of DENV have compounded the task of developing an effective Dengue treatment. ${ }^{4}$ However, vaccine candidates, such as Dengvaxia is currently under clinical trial, and tetravalent recombinant dengue vaccine was registered in Mexico, also licensed in Brazil, El Salvador and Philippines. ${ }^{5}$ An interesting alternative approach for DENV infection treatment, complex compound of cisplatin, has been therapeutically used since 1960s, and, in many instances, has proven to be effective. ${ }^{6-8}$

Copper(II) is a cofactor in the active site of the enzyme superoxide dismutase, which is, in turn, also involved in the body antioxidant defense. ${ }^{9,10}$ The metal complexes with deprotonated imidazole as ligand holds promise as an approach to enhance the biological activity. Previous reports have described the use of cobalt(II)-morin and zinc(II)-morin based systems for antiDENV type 2 applications. The value of activity inhibition of zinc(II)-morin was $2.00 \mu \mathrm{g} / \mathrm{mL}$ and cobalt(II)-morin was 3.08 $\mu \mathrm{g} / \mathrm{mL}^{11,12}$.

This study has the purpose to evaluate the antiviral activity of synthetic complex compound $[\mathrm{Cu}(2,4,5$-triphenyl- $1 H$-imidazole $\left.)_{2}\left(\mathrm{H}_{2} \mathrm{O}\right)_{2}\right] . \mathrm{Cl}_{2}$ against DENV-2. A cellbased assay screening approach was followed to identify the strongest active compound.

\section{Materials and Methods}

\section{Chemicals and Media}

Chemical reagents used in this research were $\left[\mathrm{Cu}(2,4,5 \text {-triphenyl- } 1 \mathrm{H} \text {-imidazole })_{2}\right.$ $\left.\left(\mathrm{H}_{2} \mathrm{O}\right)_{2}\right] \cdot \mathrm{Cl}_{2}$ complex compound, ${ }^{13}$ Minimum Essential Eagle Medium (Sigma-Aldrich, Germany), dengue virus serotype 2 Surabaya isolate (KT012509), Vero cells (African Green Monkey Kidney ATCC $^{\circledR}$ CCL-81), Viral ToxGlo ${ }^{\mathrm{TM}}$ assay (Promega, USA), CellTiter96 ${ }^{\circledR} \mathrm{AQ}_{\text {uoeus }}$ One Solution Cell Proliferation Assay (Promega, USA), RNA extraction kit (Qiagen, Germany), and Reverse Transcriptase-Polymerase Chain Reaction Reagent (Toyobo, Japan).

\section{Vero Cells Preparation}

Vero cell lines (African green monkey kidney) was used in this study, maintained and propagated in Minimum Essential
Correspondence: Teguh H. Sucipto, Dengue Study Group, Institute of Tropical Disease, Universitas Airlangga, Kampus C UNAIR, Jl. Mulyorejo, 60115 Surabaya, East Java, Indonesia.

E-mail: teguhharisucipto@staf.unair.ac.id

Key words: DENV-2, Vero cells, $[\mathrm{Cu}(2,4,5-$ triphenyl- $1 \mathrm{H}$-imidazole $\left.)_{2}\left(\mathrm{H}_{2} \mathrm{O}\right)_{2}\right] \cdot \mathrm{Cl}_{2}$, inhibition.

Contributions: THS, antiviral assays, manuscript writing, edited the manuscript, manuscript reviewing and references search; FM, synthesis and characterization of $[\mathrm{Cu}(2,4,5-$ triphenyl- $1 \mathrm{H}$-imidazole $\left.)_{2}\left(\mathrm{H}_{2} \mathrm{O}\right)_{2}\right] . \mathrm{Cl}_{2}$ complex compound.

Conflict of interest: the authors declare no potential conflict of interest.

Funding: Research Grant Mandat Universitas Airlangga 2019 No. 380/UN3.14/LT/2019 for research funding.

Acknowledgments: This research was supported by the Research Grant Mandat Universitas Airlangga (HRMUA) 2019; Institute of Tropical Disease (ITD) the Center of Excellence (COE) program by the Ministry of Research and Technology (RISTEK) Indonesia.

Conference presentation: The article has been presented an international conference Infectious Diseases, Biothreats, and Military Medicine (INSBIOMM).

Received for publication: 17 February 2020. Accepted for publication: 1 July 2020.

This work is licensed under a Creative Commons Attribution-NonCommercial 4.0 International License (CC BY-NC 4.0).

(C) Copyright: the Author(s), 2020

Licensee PAGEPress, Italy

Infectious Disease Reports 2020; 12(s1):8744 doi:10.4081/idr.2020.8744

Eagle Medium containing 10\% fetal bovine serum. Cultured Vero cell lines were incubated at $37{ }^{\circ} \mathrm{C}$ in $5 \% \mathrm{CO}_{2}$. Confluent monolayer of Vero cells were detached with trypsin-EDTA and incubated at $37^{\circ} \mathrm{C}$ for 5 minutes. Then, it was added Minimum Essential Eagle Medium containing 10\% fetal bovine serum, pipetting gently to break up any clumps of cells and counted using a Hemocytometer. Cells were added cells in 96-well plate with $1 \times 10^{6}$ cells $/ 10 \mathrm{~mL}$ and incubated in $37{ }^{\circ} \mathrm{C}$ incubator with $5 \mathrm{CO}_{2}$. Monitor cells daily or every other day, cells reach a $>90 \%$ confluent monolayer. ${ }^{14,15}$ 


\section{Antiviral Activity Assay}

Confluent monolayers of Vero cells were prepared on a 96-well plate $\left(1 \times 10^{6}\right.$ cells $/ 10 \mathrm{~mL}$ ) and counted using a hemocytometer, and the titer of DENV-2 $\left(2 \times 10^{4}\right.$ FFU/well) was expressed in Foci-Forming Units (FFU) after incubating at $37^{\circ} \mathrm{C}$ for 2 days. The concentrations of complex compound were $200 \mu \mathrm{g} / \mathrm{mL} ; 100 \mu \mathrm{g} / \mathrm{mL} ; 50$ $\mu \mathrm{g} / \mathrm{mL} ; 25 \mu \mathrm{g} / \mathrm{mL} ; 12.5 \mu \mathrm{g} / \mathrm{mL} ; 6.25$ $\mu \mathrm{g} / \mathrm{mL} ; 3.13 \mu \mathrm{g} / \mathrm{mL}$; and $1.57 \mu \mathrm{g} / \mathrm{mL}$ with addition $100 \mu \mathrm{L}$ Viral ToxGlo ${ }^{\mathrm{TM}}$ Assay per well. The $50 \%$ inhibitory concentration $\left(\mathrm{IC}_{50}\right)$ of DENV-2 replication by each compound was further investigated by using GloMax ${ }^{\circledR}$ Discover System.

\section{Cytotoxicity Assay}

A cytotoxicity assay was performed using CellTiter96 ${ }^{\circledR}$ AQuoeus One Solution Cell Proliferation reagent. The CellTiter96 ${ }^{\circledR}$ Assay is a modification of the MTT assay method portrayed by Mosman. ${ }^{16}$ The concentrations of $[\mathrm{Cu}(2,4,5$-triphenyl$1 \mathrm{H}$-imidazole $\left.)_{2}\left(\mathrm{H}_{2} \mathrm{O}\right)_{2}\right] . \mathrm{Cl}_{2}$ were 200 $\mu \mathrm{g} / \mathrm{mL} ; 100 \mu \mathrm{g} / \mathrm{mL} ; 50 \mu \mathrm{g} / \mathrm{mL} ; 25 \mu \mathrm{g} / \mathrm{mL}$; and $12.5 \mu \mathrm{g} / \mathrm{mL}$. The medium was allowed to equilibrate for 1 hour; then $20 \mu \mathrm{L} /$ well of CellTiter 96® AQueous One Solution Reagent was added. After 1 hour at $37^{\circ} \mathrm{C}$ in a humidified, $5 \% \mathrm{CO}_{2}$ atmosphere, the absorbance at $490 \mathrm{~nm}$ was recorded using GloMax ${ }^{\circledR}$ Discover System.

\section{Viral Detection by Reverse Transcriptase-Polymerase Chain Reaction}

RNA replication was estimated using the Reverse Transcriptase-Polymerase Chain Reaction (RT-PCR). The purpose of this assay was to known RNA replication after treatment. Briefly, DENV-2 RNA was extracted from the DENV-2 infected cells by Qiagen RNA Extraction Kit, Germany. The two-step kit (Toyobo, Japan) was used for cDNA synthesis and Polymerase Chain Reaction (PCR) following manufacturer's instructions. Primer oligonucleotide sequences were as follows by Lanciotti et al. ${ }^{17}$ Amplification condition was $54{ }^{\circ} \mathrm{C}$ for one minute (annealing temperature) and the amplified product was the analyzed on $1.5 \%$ agarose gel.

\section{Statistical Analysis}

Logarithmic regression analysis to calculate the $50 \%$ toxic concentration in assays and $\mathrm{T}$ test was performed to determine the significance of the difference between sets of data using SPSS 21.0 version. A P-value of $<0.05$ was considered statistically significant.

\section{Results}

Anti-DENV2 Activity by $[\mathrm{Cu}(2,4,5-$ triphenyl- $1 \mathrm{H}$-imidazole $\left.)_{2}\left(\mathrm{H}_{2} \mathrm{O}\right)_{2}\right] \cdot \mathrm{Cl}_{2}$

Dengue virus serotype 2 (DENV-2) in Vero cells infected was treated with various concentration of $[\mathrm{Cu}(2,4,5$-triphenyl- $1 \mathrm{H}$ imidazole $\left.)_{2}\left(\mathrm{H}_{2} \mathrm{O}\right)_{2}\right] \cdot \mathrm{Cl}_{2}$ in infect to the Vero cells. The concentrations of compound were $200 \mu \mathrm{g} / \mathrm{mL} ; 100 \mu \mathrm{g} / \mathrm{mL} ; 50 \mu \mathrm{g} / \mathrm{mL} ; 25$ $\mu \mathrm{g} / \mathrm{mL} ; 12.5 \mu \mathrm{g} / \mathrm{mL} ; 6.25 \mu \mathrm{g} / \mathrm{mL} ; 3.13$ $\mu \mathrm{g} / \mathrm{mL}$; and $1.57 \mu \mathrm{g} / \mathrm{mL}$. Medium control and cell control without DENV-2. The data distribution of the luminescence from each concentration was normal, with p-value more than 0.05 . The luminescence is a total energy response from cell mitochondrial in each concentration of compound. The Table 1 showed the average luminescence with its standard deviation (Stdev).

The luminescence was then further calculated as percentage viability of the virus upon treatment. The equation of the logarithmic regression curve showed the half inhibition concentration $\left(\mathrm{IC}_{50}\right)$.

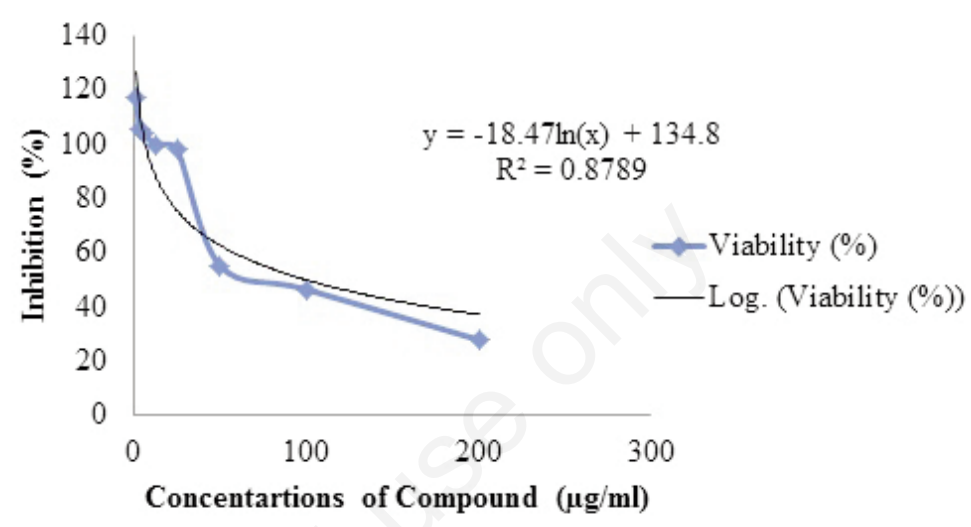

Figure 1. Regression curve of the inhibited DENV-2 after treatment with $[\mathrm{Cu}(2,4,5$-triphenyl- $1 \mathrm{H}$-imidazole $\left.)_{2}\left(\mathrm{H}_{2} \mathrm{O}\right)_{2}\right] \cdot \mathrm{Cl}_{2}$

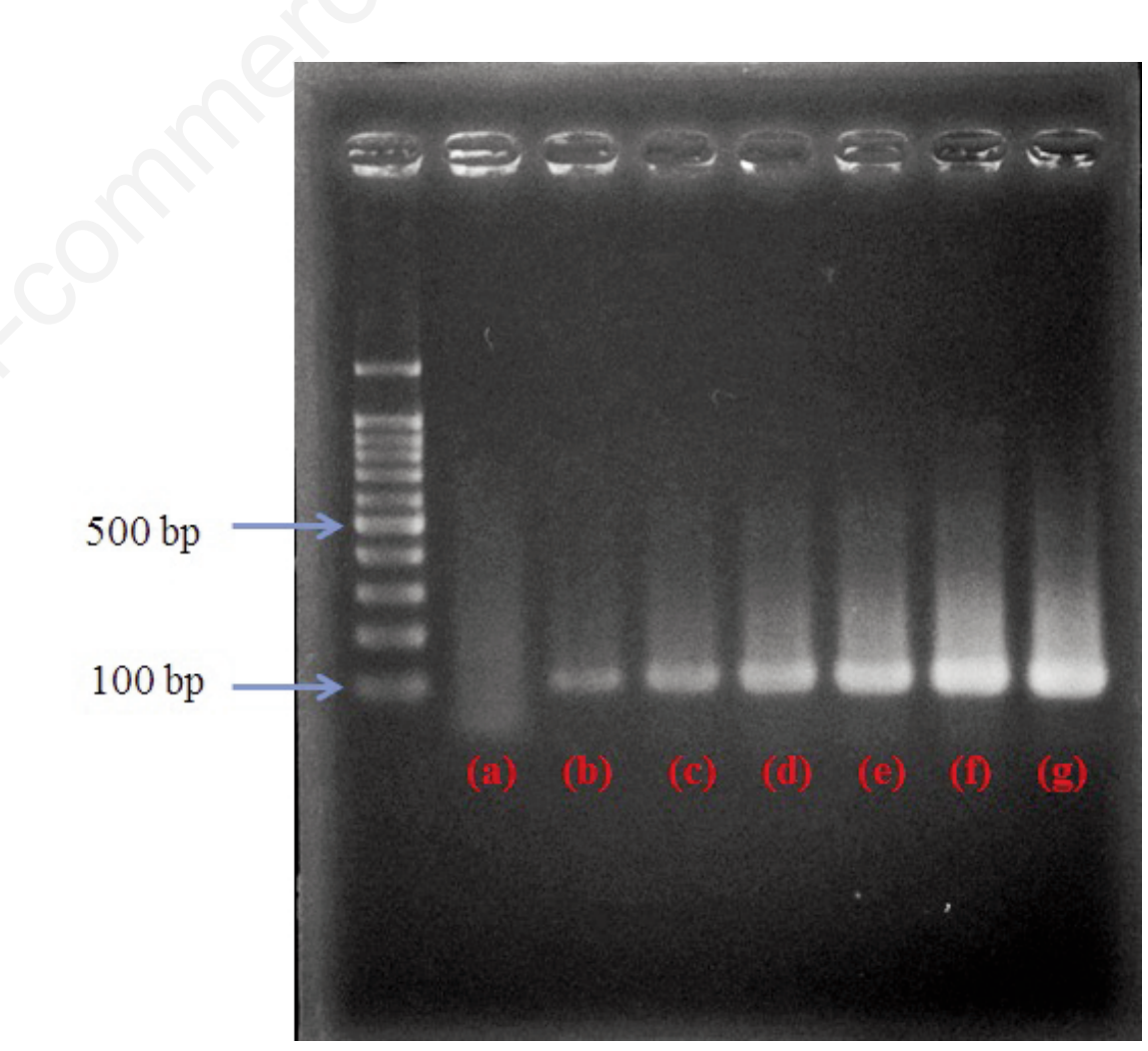

Figure 2. Electrophoresis on $1.5 \%$ agarose of RT-PCR after treatment, molecular weight marker (100 bp), (a) negative control, (b) $200 \mu \mathrm{g} / \mathrm{mL}$, (c) $100 \mu \mathrm{g} / \mathrm{mL}$, (d) $50 \mu \mathrm{g} / \mathrm{mL}$, (e) $25 \mu \mathrm{g} / \mathrm{mL}$, (f) $12.5 \mu \mathrm{g} / \mathrm{mL}$, and (g) $6.25 \mu \mathrm{g} / \mathrm{mL}$ 
The viral inhibition was increased as the $\left[\mathrm{Cu}(2,4,5 \text {-triphenyl- } 1 \mathrm{H} \text {-imidazole })_{2}\right.$ $\left.\left(\mathrm{H}_{2} \mathrm{O}\right)_{2}\right] \cdot \mathrm{Cl}_{2}$ concentration was increased (Table 2 and Figure 1). DNA amplification result of DENV-2 was decreased as the complex compound increased (Figure 2). The $50 \%$ inhibitory concentration $\left(\mathrm{IC}_{50}\right)$ of $\left[\mathrm{Cu}(2,4,5 \text {-triphenyl- } 1 \mathrm{H} \text {-imidazole })_{2}\right.$ $\left.\left(\mathrm{H}_{2} \mathrm{O}\right)_{2}\right] \cdot \mathrm{Cl}_{2}$ against DENV-2 was 98.62 $\mu \mathrm{g} / \mathrm{mL}$.

\section{Cytotoxicity Effect of $[\mathrm{Cu}(2,4,5-$ triphenyl- $1 \mathrm{H}$-imidazole $\left.)_{2}\left(\mathrm{H}_{2} \mathrm{O}\right)_{2}\right] \cdot \mathrm{Cl}_{2}$}

The $\mathrm{CC}_{50}$ was analyzed by the polynomial regression equation showing cell viability (Figure 3 ). The $50 \%$ cytotoxicity concentration $\left(\mathrm{CC}_{50}\right)$ of $[\mathrm{Cu}(2,4,5$-triphenyl$1 \mathrm{H}$-imidazole $\left.)_{2}\left(\mathrm{H}_{2} \mathrm{O}\right)_{2}\right] . \mathrm{Cl}_{2}$ to Vero cells was $300.36 \mu \mathrm{g} / \mathrm{mL}$.Vero cells were treated with various concentrations $200 \mu \mathrm{g} / \mathrm{mL} ; 100$ $\mu \mathrm{g} / \mathrm{mL} ; 50 \mu \mathrm{g} / \mathrm{mL} ; 25 \mu \mathrm{g} / \mathrm{mL}$; and 12.5 $\mu \mathrm{g} / \mathrm{mL}$. Table 3 showed the cytotoxicity effect percentage. After the $\mathrm{CC}_{50}$ was divided by $\mathrm{IC}_{50}$, selectivity index of $[\mathrm{Cu}(2,4,5$ triphenyl- $1 H$-imidazole $\left.)_{2}\left(\mathrm{H}_{2} \mathrm{O}\right)_{2}\right] . \mathrm{Cl}_{2}$ in this study was 1.86 .

The Vero cells also were observed in the microscopic images after treatment in each concentration of complex compound. In the present study, the apoptotic cell rates were determined for the Vero cells stimulated by the complex compound in different concentration for $24 \mathrm{~h}$. The results showed that these complex compound stimulated apoptotic of Vero cells compared with control, for example in the $200 \mu \mathrm{g} / \mathrm{mL}$ concentration of complex compound induced probability apoptotic in $90 \%$ of the cells, seen in the Figure 4.

\section{Discussion}

Antiviral drug to DENV has been developing rapidly and profoundly in many countries. Complex compounds are a potential source for the development of new antiviral drugs. These compounds produce a variety constituent with the potential to inhibit viral replication and are of interested as possible sources to control viral infection. ${ }^{18-20}$ As a result, a substance that is going to be used for treatment needs to be effective and safe. Selectivity index is a ratio between the cytotoxic and the inhibitory capacity of a substance $\left(\mathrm{CC}_{50} / \mathrm{IC}_{50}\right)$, to measure the effectiveness and safety of a product. $^{21,22}$

The aim of this study is to find antiviral to DENV-2 using Vero cells line. Vero cells could be infected by DENV as well as hepatocyte cell because the characteristic of the cell is similar to hepatocyte in which basi-

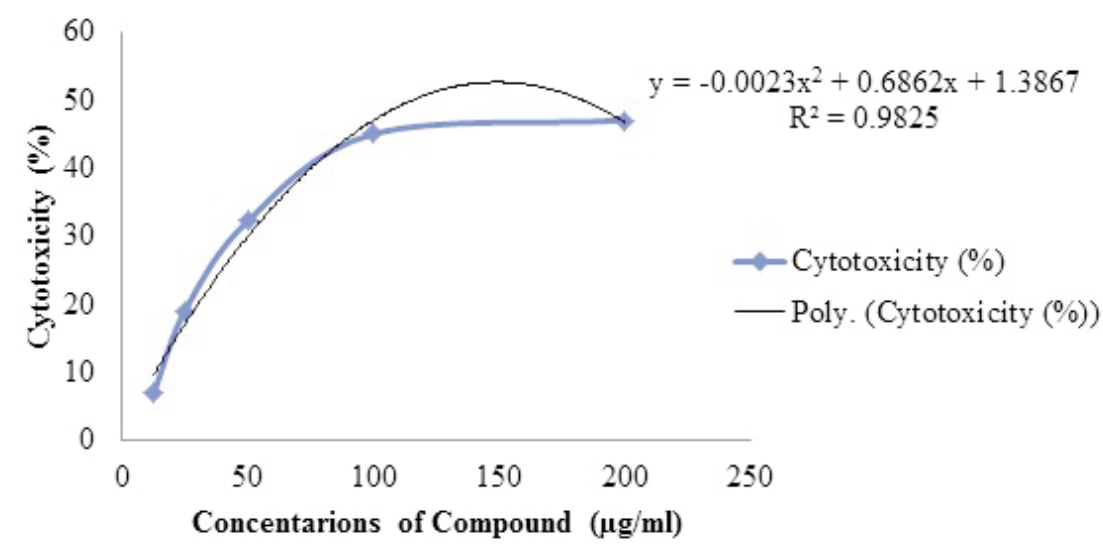

Figure 3. Regression curve of the cytotoxicity of Vero cells after treatment with $\left[\mathrm{Cu}(2,4,5 \text {-triphenyl-1 } \mathrm{H} \text {-imidazole })_{2}\left(\mathrm{H}_{2} \mathrm{O}\right)_{2}\right] \cdot \mathrm{Cl}_{2}$

Table 1. Luminescence of DENV-2 treatment with various concentration of $[\mathrm{Cu}(2,4,5$ triphenyl- $1 \mathrm{H}$-imidazole $\left.)_{2}\left(\mathrm{H}_{2} \mathrm{O}\right)_{2}\right] . \mathrm{Cl}_{2}$ with $\mathrm{p}$ value $<0.05$

\begin{tabular}{lcc} 
Treatment $(\mu \mathrm{g} / \mathrm{mL})$ & Stdev \\
200 & 1.01 & 0.198 \\
100 & 1.68 & 0.595 \\
\hline 50 & 2.00 & 0.814 \\
25 & 3.55 & 1.443 \\
\hline 12.5 & 3.62 & 3.596 \\
6.25 & 3.77 & 0.323 \\
\hline 3.13 & 3.84 & 1.865 \\
1.57 & 4.26 & 0.560 \\
\hline Medium Control & 9.44 & 4.460 \\
Cell Control & 3.63 & 0.002 \\
\hline
\end{tabular}

Table 2. Inhibited DENV-2 treatment with $\left[\mathrm{Cu}(2,4,5 \text {-triphenyl- } 1 \mathrm{H} \text {-imidazole })_{2}\right.$ $\left.\left(\mathrm{H}_{2} \mathrm{O}\right)_{2}\right] \cdot \mathrm{Cl}_{2}$.

Concentration of Complex Compound ( 1 g/g/mL) Inhibition (\%)

\begin{tabular}{cc}
200 & 27.72 \\
100 & 46.30 \\
\hline 50 & 55.07 \\
25 & 97.83 \\
\hline 12.5 & 99.83 \\
6.25 & 103.88 \\
\hline 3.13 & 105.79 \\
1.57 & 117.49 \\
\hline
\end{tabular}

Table 3. The viability Vero cells after treatment with $[\mathrm{Cu}(2,4,5-$ triphenyl- $1 H$ imidazole $\left.)_{2}\left(\mathrm{H}_{2} \mathrm{O}\right)_{2}\right] \cdot \mathrm{Cl}_{2}$.

\begin{tabular}{cc}
200 & 47.02 \\
100 & 45.04 \\
\hline 50 & 32.26 \\
25 & 19.10 \\
\hline 12.5 & 6.94 \\
\hline
\end{tabular}



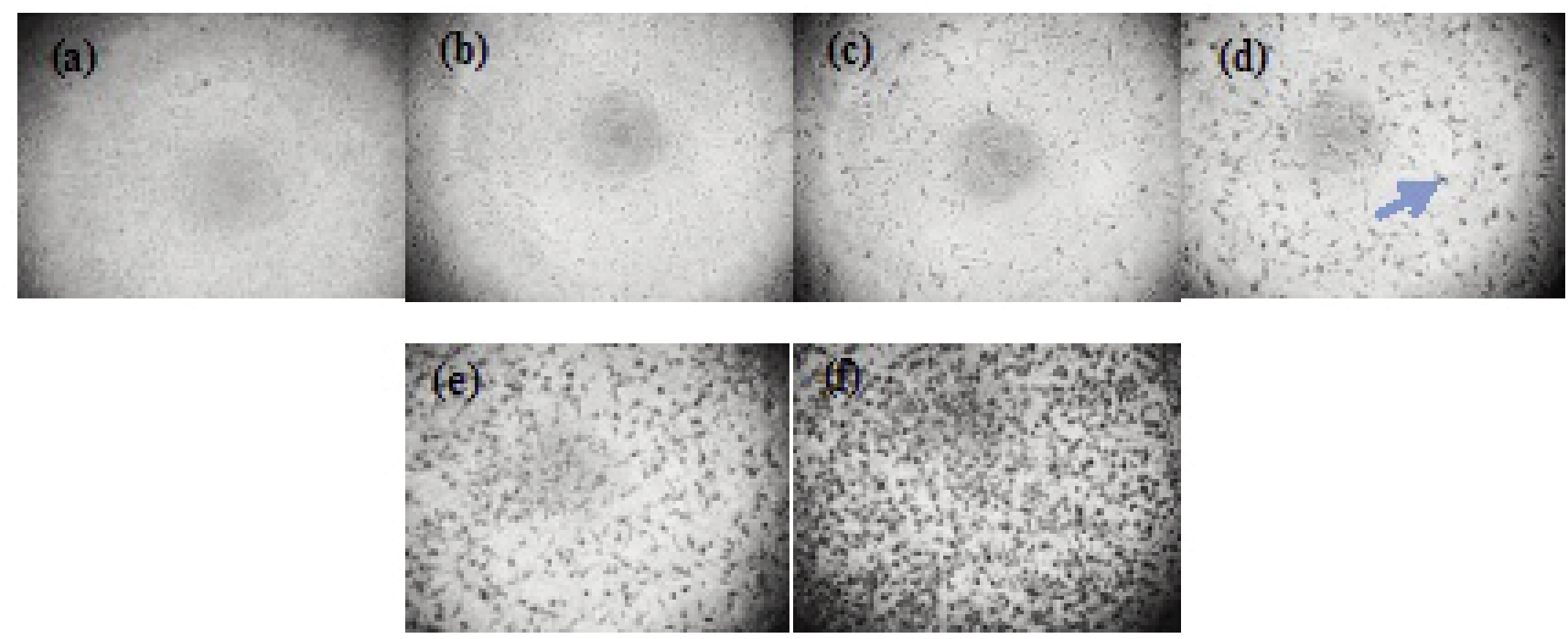

Figure 4. Vero cells conditions after treatment under microscope (40x). (a) normal Vero cells (control); (b) concentration $12.5 \mu \mathrm{g} / \mathrm{mL}$; (c) concentration $25 \mu \mathrm{g} / \mathrm{mL}$; (d) concentration $50 \mu \mathrm{g} / \mathrm{mL}$; (e) concentration $100 \mu \mathrm{g} / \mathrm{mL}$; and (f) concentration $200 \mu \mathrm{g} / \mathrm{mL}$. The blue arrow shows apoptosis cell caused by interaction with complex compound.

cally the place of dengue virus to replicate itself. $^{22}$

The $50 \%$ cytotoxic concentration is a concentration of a compound in which it may reduce the viability of a cell by $50 \%$. It was found that $\mathrm{CC}_{50}$ of $[\mathrm{Cu}(2,4,5$-triphenyl$1 \mathrm{H}$-imidazole $\left.)_{2}\left(\mathrm{H}_{2} \mathrm{O}\right)_{2}\right] . \mathrm{Cl}_{2}$ was 300.36 $\mu \mathrm{g} / \mathrm{mL}$ and percentage of Vero cell viability were decreased in higher concentration.

This study found that the $\mathrm{IC}_{50}$ of $\left[\mathrm{Cu}(2,4,5 \text {-triphenyl- } 1 H \text {-imidazole })_{2}\right.$ $\left.\left(\mathrm{H}_{2} \mathrm{O}\right)_{2}\right] . \mathrm{Cl}_{2}$ was $98.62 \mu \mathrm{g} / \mathrm{mL}$ and percentage of DENV-2 inhibition was increased in higher concentration. The data in this study was analyzed by using t-test on SPSS 21.0 version and inhibition of compound to DENV-2 replication was significant ( $P$ $<0.05$ ). In the previous study, $\mathrm{Cu}$ (II)-imidazole was reactive to DENV-2 with $\mathrm{IC}_{50} 2.3$ $\mu \mathrm{g} / \mathrm{mL},{ }^{23}$ bioactivity occurs within the imidazole series of a "para-" position to its 'C'terminal. ${ }^{24} \mathrm{C}$ terminal in the imidazole structure has a big function in introduced to improve cellular uptake and nuclear localization of complex compound.Besides that phenyl-imidazole has a great potential as drug candidate to treatment a variety of viral diseases, phenyl rings in imidazole presence of electron withdrawing groups improved the biological activity. ${ }^{25}$

Copper is a bio-essential element and copper complexes have been extensively utilized in metal mediated DNA cleavage for generation of activated oxygen species, was reported that teraazamacrocyclic copper coordination compounds have anti-HIV activity. ${ }^{20}$ Copper(II)chloride dihydrate was reported toxic to DENV-2, $\mathrm{IC}_{50} 0.13 \mu \mathrm{g} / \mathrm{mL}$. Free copper(II) homeostatic mechanisms play an important role in the prevention of copper toxicity, exposure to excessive levels of copper can result in a number of adverse health effects. ${ }^{26}$ In the previous study about interactions of $\mathrm{Cu}^{2+}$ ion with fragments of envelope protein of virus was found that a peptide having no competitive binding site in the amino acid side-chains usually begins its coordination to the metal ion via N-terminal amino group in DNA. The $\mathrm{Cu}^{2+}$ ion promotes the ionization of protons from successive peptide nitrogen. ${ }^{27}$

Apoptosis (cell death) is the main form of cell death that is involved in diverse processes ranging from cell development to stress response and definite morphological changes. ${ }^{28,29}$ In many cases, apoptosis occurs in response to physiological stimuli such as osmotic modifications, virus infection effect, and effect from compound product. ${ }^{30}$ In the present study, Vero cells exposed to [ $\mathrm{Cu}(2,4,5 \text {-triphenyl- } 1 \mathrm{H} \text {-imidazole })_{2}$ $\left.\left(\mathrm{H}_{2} \mathrm{O}\right)_{2}\right] \cdot \mathrm{Cl}_{2}$ complex compound reduced the viability indicating the characteristic pattern of cell death. This assay is a modify methods from MTT by Mosmann, most sensitive cytotoxicity assay that is mainly based on the enzymatic conversion with mitochondria. Despite the complexity of the mechanisms involved, mitochondria appear to release apoptosis-inducing factors that may trigger DNA fragmentation in nuclei. ${ }^{31}$ Mitochondria are common integrators and transducers of various proapoptotic signals, and mitochondria membrane permeabilization is the rate limiting manifestation of mitochondria cell death. ${ }^{32}$

\section{Conclusions}

The $[\mathrm{Cu}(2,4,5$-triphenyl- $1 H$-imidazole $\left.)_{2}\left(\mathrm{H}_{2} \mathrm{O}\right)_{2}\right] . \mathrm{Cl}_{2}$ complex compound has antiviral effect to DENV-2 without low cytotoxicity effect to Vero cells. Future studies are needed to investigate the $\mathrm{IC}_{50}$ and $\mathrm{CC}_{50}$ value and mechanism of antiviral action, such as entry or post entry DENV-2 infection.

\section{References}

1. Gubler DJ. Dengue and dengue hemorrhagic fever. Clin Micobiol Rev 1998;11:480-96

2. Gubler DJ. Dengue/dengue haemorrhagic fever: history and current status. Novartis Found Symp 2006;277:3-16

3. Ooi EE, Gubler DJ. Dengue in Southeast Asia: epidemiological characteristics and strategic challenges in disease prevention. Cad Saúde Pública 2009;25:S115-S124

4. Holmes EC, Bartley LM, Garnett GP. 10 the emergence of dengue: past present and future. Biomed Res Rep 1998;1:301-325

5. World Health Organization. Dengue vaccine research; 2017. Available from: https:/www.who.int/immunization/rese arch/development/dengue_vaccines/en Accessed: September 21, 2019

6 . Kelland L. The resurgence of platinumbased cancer chemotherapy. Nat Rev Cancer 2007;7:573-584

7. Frezza M, Hindo S, Chen D, et al. Novel metals and metal complexes as 
platforms for cancer therapy. Curr Pharm Des 2010;16:1813-1825

8. Dasari S and Tchounwou PB. Cisplatin in cancer therapy: molecular mechanisms of action. Eur J Pharmacol 2014;0:364-378

9. Mello LD, Pereira RM, Sawaya AC, et al. Electrochemical and spectroscopic characterization of the interaction between DNA and $\mathrm{Cu}(\mathrm{II})$-naringin complex. J Pharm Biomed Analysis 2007;45:706-713

10. Trofimova NN, Babkin VA, Kiselev OI. Complex compounds of zinc and copper(II) ions with dihydroquercetin and their antiviral activity. Russ Chem Bull 2015;64:1430-1436

11. Sucipto TH, Setyawati H, Churrotin S, et al. Anti-dengue type 2 virus activities of zinc(II) complex compounds with 2 (2,4-dihidroxyphenyl)-3,5,7-trihydroxycromen-4-one ligands in vero cells. Indonesian J Trop Infect Dis 2019;7: 105-108

12. Sucipto TH, Churrotin S, Setyawati H, et al. Inhibitory activity of cobalt(II)morin complex against the replication of dengue virus type 2. Indonesian $\mathrm{J}$ Trop Infect Dis 2017;6:141-144

13. Sucipto TH, Setyawati H, Murwani IK, Martak F. Synthesis, characterization, and anticancer activity against human breast cancer cell line T74D studies of metal ion $\mathrm{Cu}$ (II) complex with 2,4,5triphenylimidazole ligand. Afr J Pharm Pharmacol 2018;12:421-426

14. Ammerman NC, Beier-Sexton M, Azad AF. Growth and maintenance of vero cell lines. CurrProtocMicrobiol 2009;11:1-10

15. Plotkin BJ, Sigar IM, Swartzendruber
JA, Kaminski A. Anaerobic growth and maintenance of mammalian cell lines. J Vis Exp 2018;137: 1-6

16. Mosmann T. Rapid colorimetric assay for cellular growth and survival: Application to proliferation and cytotoxicity assays. J Immunol Methods. 1983;65:55-63.

17. Lanciotti RS, Calisher CH, Gubler DJ, et al. Rapid detection and typing of dengue viruses from clinical samples by using reverse transcriptase-polymerase chain reaction. $\mathrm{J}$ Clin Microbiol 1992;30:545-51

18. Clercq ED. Antiviral metal complexes. Met Based Drugs 1997;4:173-192

19. Galal SA, Abd El-All AS, Hegab KH, et al. Novel antiviral benzofuran-transition metal complexes. Eur J Med Chem 2010;45:3035-46

20. Sucipto TH, Martak F. Synthesis of metal-organic (complexes) compounds copper(II)-imidazole for antiviral HIV candidate. Indonesian J Trop Infect Dis 2016;6:5-11

21. Muhammad M, Kee LY, Rahman NA, Yusof R. Antiviral actions of flavonoidderived compounds on dengue virus type-2. Int J BiolSci 2010;6:294-302

22. Ichsyani M, Ridhanya A, Risanti M, et al. Antiviral effects of Curcuma longa L. against dengue virus in vitro and in vivo. IOP ConfSer: Earth Environ Sci 2017;101:1-11

23. Sucipto TH, Churrotin S, Setyawati H, et al. New copper(II)-imidazole derivative effectively inhibits replication of DENV-2 in Vero cell. Afr $J$ Infect Dis;12:116-119

24. Saudi M, Zmurko J, Kaptein S, et al. Synthesis and evaluation of imidazole-
4,5- and pyrazine-2,3- dicarboxamides targeting dengue and yellow fever virus. Eur J Med Chem 2014;87:529-539

25. Sharma D, Narasimhan B, Kumar P, et al. Synthesis, antimicrobial and antiviral evaluation of substituted imidazole derivatives. Eur J Med Chem 2009;44:2347-2353

26. Iakovidis I, Delimaris I, Piperakis SM. Copper and its complexes in medicine: A biochemical approach. Mol Biol Int 2011;2011:1-14

27. Chruściński L, Dyba M, JeżowskaBojczuk M, et al. Specific interactions of $\mathrm{Cu} 2+$ ions with fragments of envelope protein of hepatitis B virus. J Inorg Biochem 1996;63:49-55

28. Sreelatha S, Jeyachitra A, Padma P. Antiproliferation and induction of apoptosis by Moringaoleifera leaf extract on human cancer cells. Food Chem Toxicol 2011;49:1270-1275

29. Murugavel P, Pari L, Sitasawad SL, et al. Cadmium induced mitochondrial injury and apoptosis in vero cells: protective effect of diallyltetrasulfide from garlic. Int $\mathrm{J}$ Biochem Cell Biol 2007;39:161-170

30. Sadzot-Delvaux C, Thonard P, Schoonbroodt S, et al. Varicella-zoster virus induces apoptosis in cell culture. J. Gen Virol 1995;76:2875-2879

31. Sunsin SA, Lorenzo HK, Zamzami N, et al. Mitochondrial release of caspase2 and -9 during the apoptotic process. J Exp Med 1999;189:381-394

32. Desagher S, Martinou JC. Mitochondria as the central control point of apoptosis. Trends Cell Biol 2000;10:369-377. 